\title{
小形風車ブレードの等価疲労荷重評価法への一提案
}

\author{
徳山 榮基 ${ }^{* 1}$ ，高橋 徹 ${ }^{* 2}$, 飯野 光政 ${ }^{* 3}$, 飯田 誠 ${ }^{* 4}$
}

\section{Proposal of an evaluation method of equivalent fatigue load for small wind turbine blade}

\author{
Hideki TOKUYAMA $^{* 1}$, Toru TAKAHASHI ${ }^{* 2}$, Mitsumasa IINO ${ }^{* 3}$ and Makoto IIDA ${ }^{* 4}$ \\ 5-28, Shinsuna 3 Koto-ku, Tokyo, 136-0075, Japan \\ ${ }^{* 3}$ The University of Tokyo Department of Advanced Interdisciplinary Studies \\ 4-6-1 Komaba, Meguro-ku, Tokyo 153-8904, Japan \\ ${ }^{*} 4$ The University of Tokyo Research Center for Advanced Science and Technology \\ 4-6-1 Komaba, Meguro-ku, Tokyo 153-8904, Japan
}

Received 31 January 2014

\begin{abstract}
This study is carried out for the purpose of collecting data that is based on the evaluation of the equivalent fatigue load for a small wind turbine. The equivalent fatigue load is indicated as the method of designing load calculation in IEC 61400-2 ed.2 DLC1.1. In this study, it is performed fatigue load test for the commercial model of the small wind turbine, and it is evaluated the applicability of S-N diagram as material specification and the material factor " $m$ " for S-N diagram model. It is cleared that $\mathrm{S}-\mathrm{N}$ diagram as material specification is able to apply to the evaluation for blade fatigue load. Moreover, it is indicated experimentally the material factor " $m$ " of 10 to a single material of G-FRP that is composed as general small wind turbine's blades. Furthermore, it is suggested the estimated method of the equivalent fatigue load by using the fatigue load function of Simplified Load Model (SLM) and it is made a trial calculation by this method.
\end{abstract}

Key words : Small wind turbine, Blade fatigue load test, Evaluation of equivalent fatigue load

\section{1. 緒言}

近年小形風力発電は「設置面積が小さく場所を取らない」「設置, 運搬が容易」「設置から運用までの期間が短 い」などの利点を活かせる地域において，途上国だけでなく日本国内においても導入が進んでいる．特に数 $\mathrm{kW}$ の風車は，山岳部や離島などの電力脆弱地域で活用されている．さらに最近の小形風力発電機は，新たな風資源 として建屋屋上設置など市街地でも設置環境としての検討が進み，その普及拡大が期待されている．今後小形風 力発電機により電力需給効果を高めるには, 発電特性だけでなく信頼性の高い安全な製品を安定的に供給できる ことが重要となる．このような背景の中， 2012 年度から小形風力発電の安全性·信頼性を第三者機関によって審 査する「型式認証制度」がスタートしている. 本制度は, 小形風車の国際標準である IEC 61400-2 と一部国内情 勢を考慮し制定され, 各主要部品の強度設計評価に加えて, フィールド試験により性能·騒音・耐久性を審査し, その製品に対して認証を与えるものである(赤星, 2012)（日本小形風力発電協会, 2011). IEC 61400-2 では強度設

No. 14-00054 [DOI: 10.1299/transjsme.2014tep0232]

*1 正員, 那須電機鉄工(株) (广136-0075 東京都江東区新砂 3-5-28)

*2 那須電機鉄工(株)

*3 正員, 東京大学大学院 工学系研究科（干153-8904 東京都目黒区駒場 4-6-1）

*4 正員, 東京大学 先端科学技術研究センター産学連携新エネルギー研究施設

E-mail of corresponding author: tokuyama@nasudenki.co.jp 
計評価法の中で，簡便で計算負荷の小さいものとして簡易荷重計算モデル(SLM)が示されており, 多くのメーカ が活用している(International electrotechnical commission, 2006). しかしながら当該計算モデルは一部便宜的な手法 となっており，その妥当性における技術的見解について現在もなお議論されている．中でも疲労荷重ケースにお けるSLM の適用性を十分評価した事例はほとんどない，そこで本研究では，小形風車の疲労設計をより合理的 かつ経済的に行うことを目的とし，その一提案として IEC 61400-2 に記載の SLM による疲労荷重評価の適用性に ついて検討した．まず，小形風車のブレードとして多く採用されている単一構成材料による実機ブレードでの繰 り返し荷重実験を実施し, 等価疲労荷重による寿命評価に資するデータの収集を行った. さらに SLMをもとに 疲労荷重の頻度分布を推定する方法を提案し，等価疲労荷重による疲労評価を試みた.

\section{IEC 61400-2 簡易荷重計算モデルにおける疲労評価}

IEC 61400-2 ed.2 の簡易荷重モデル(SLM)における疲労荷重は，設計風速 $\left(V_{\text {design }}=1.4 V_{\text {ave }}\right)$ をもとに風車は $0.5 V_{\text {design }}$ から $1.5 V_{\text {design }}$ の範囲で変動するとし荷重振幅を求める考えであり, 翼根部のフラップ曲げモーメントは式(1)で与 えられる， $V_{\mathrm{ave}}$ は当該標準で示された年間平均風速を意味し，風車の設計クラスによって区分され，クラス I の場 合 $V_{\text {ave }}$ は $10 \mathrm{~m} / \mathrm{s}$ であり，そのときの $V_{\text {design }}$ は $14 \mathrm{~m} / \mathrm{s}$ となる. IEC 61400-2 ed.2 では, SLM にて求められたフラップ 曲げモーメントの振幅に対して, 翼の疲労特性が未知の場合, 材料安全率を 10 として静的な応力評価を行い, 通 常運転状態での疲労強度について評価する. (International electrotechnical commission, 2006) また疲労寿命の推定は, マイナー則による評価が示されている，当該標準では，式(1)のモーメント振幅 $\Delta M_{y B}$ が，24 時間 365 日つねに作 用寸ることを想定している. また当該標準では,その特定された振幅の変動荷重の発生頻度は式(2)によって求めら れる. なお式(1)の $\lambda_{\text {design }}$ は設計周速比， $Q_{\text {design }}$ は設計トルク(Nm)， B はブレード枚数である.また，式(2)の $T_{d}$ は 風車設計寿命 $(\mathrm{sec}), n$ は疲労サイクル数である. なお $n_{\text {design }}$ は設計回転数であり式(2)では定数として扱われるもの である.つまり SLM で示されたブレードフラップ方向の疲労荷重は, 非常に短い周期 ( 1 秒間で十数回を超える) で発生し, その荷重が $V_{\text {design }}$ の風速で特定される単一の荷重振幅 $\Delta M_{y B}$ として常に作用し続けると解釈出来る (International electrotechnical commission, 2006). ブレードに作用寸る疲労荷重は，風速の発生頻度に依存した分布 を伴う荷重である，一方前述した SLM での疲労荷重評価は， $V_{\text {design }}$ により特定された単一の荷重振幅を想定する ため, 実際に風車が経験するものとは異なる. よって小形風車の疲労設計を, より実際に見合った手法に行うと いった検討は, 今後の小形風力発電機の信頼性向上にとって重要なものとなる.

$$
\begin{aligned}
& \Delta M_{y B}=\frac{\lambda_{\text {design }} Q_{\text {design }}}{B} \\
& n=\frac{B n_{\text {design }} T_{d}}{60}
\end{aligned}
$$

\section{3. 実験方法および供試風車}

\section{$3 \cdot 1$ 供試風車}

本実験の対象とする風車を図 1 , 表 1 に示す.

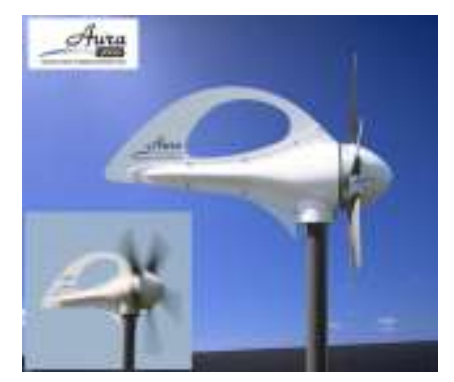

Fig. 1 AURA1000
Table 1 Specification (AURA1000)

\begin{tabular}{|l|l|}
\hline \multicolumn{2}{|c|}{ AURA1000 } \\
\hline Rated Power & $135 \mathrm{~W}(10 \mathrm{~m} / \mathrm{s})$ \\
\hline Maximum Power & $500 \mathrm{~W}$ (Battery 24V) \\
\hline Cut-out Wind Speed & $16 \mathrm{~m} / \mathrm{s} \quad$ (Battery 24V) \\
\hline Cut-in Wind Speed & $2.0 \mathrm{~m} / \mathrm{s}$ \\
\hline Survival Wind Speed & $60 \mathrm{~m} / \mathrm{s}$ \\
\hline Rotor Diameter & $1000 \mathrm{~mm}$ \\
\hline
\end{tabular}


Tokuyama, Takahashi, Iino and Iida, Transactions of the JSME (in Japanese), Vol.80, No.816 (2014)

この風車は那須電機鉄工製 AURA1000 であり，直径 $1 \mathrm{~m}$ の風車である.ブレード材料は，プロピレン系の熱可 塑性ガラス繊維強化材（ガラス含有率 $30 \%$ ） であり, 単一構成部材となる. 定格 $2 \mathrm{~kW}$ 程度の風車までは, G-FRP 材にしてもプリプレグ材を使用寸るなど，単一構成部材が多い. 本供試風車ブレードは, IEC 61400-2 の適用対象 である.

\section{$3 \cdot 2$ 実験装置および方法}

本研究で使用する繰り返し荷重試験器は, 鷺宮製作所製の油圧サーボ加振器 (PAQ II) を用いた. 変位または荷重 制御による正弦波の振幅を与えることができる.（図 2)ブレードは実製品の八ブに取り付け，その八ブを架台に 取り付けた. サーボ加振器のシャフト先端部を図 3 に示寸点 $P L$ 位置に固定することで, 集中荷重としてフラップ 方向の繰り返し荷重を印加した. フラップ方向曲げモーメント振幅における最弱部(翼根部)を評価対象部とし, 応 力振幅 $\left(\Delta \sigma_{y B}\right)$ をもとに疲労評価を行った．なお本研究では，解析ソフト「ANSYS」にてブレード製造型に利 用した 3D モデルによる有限要素解析および静荷重実験を事前に実施し、求められたフラップ曲げモーメン トと発生応力をもとに想定したモーメント振幅と応力振幅の関係を表 2 のように定めた. なお表 2 の值は, 静 荷重試験によるフラップ方向破断曲げモーメント，および当該材料の引張り強さ (130 MPa) により正規化したも のである (以降、正規化応力振幅 : $\Delta \sigma_{y B}$, 正規化モーメント振幅 : $\Delta M_{y B}$ ). 本実験の供試験ブレードには, 評価対 象部に歪みゲージを貼り，実験初期段階では応力振幅を測定し，想定応力振幅を確認した．材料の亀裂・破断回 数は，歪みゲージの急激な変化(ゲージ破断による) と目視観察による亀裂確認により判断した.

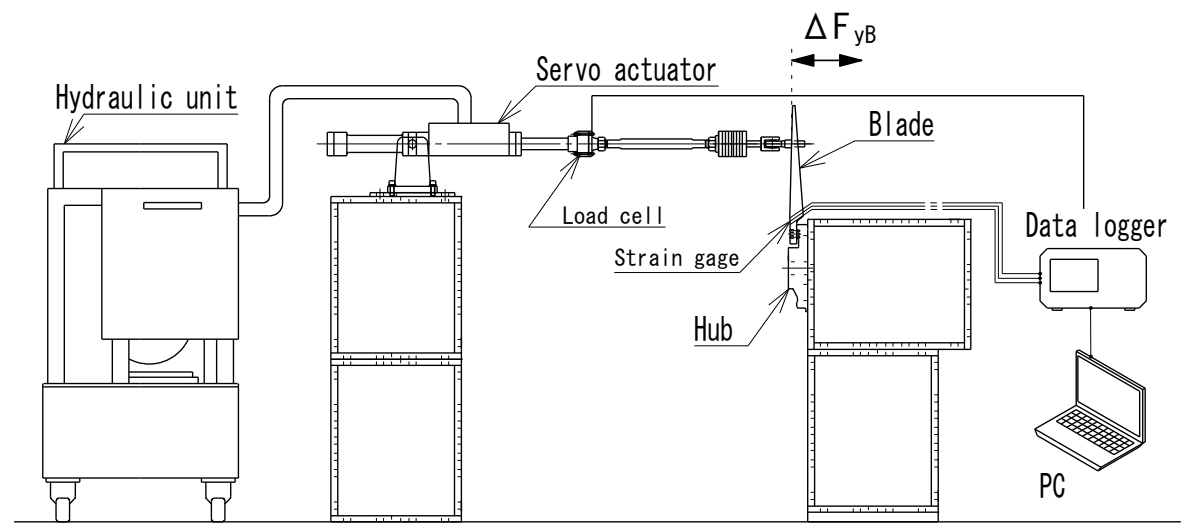

Fig. 2 Fatigue load test apparatus

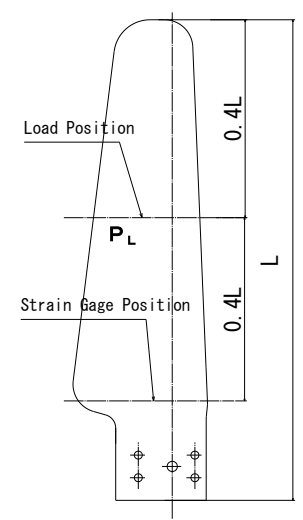

Fig. 3 Load position

Table 2 Load condition

\begin{tabular}{|c|c|c|c|}
\hline No. & $\begin{array}{c}\text { Normalized Blade Bending } \\
\text { Moment } \Delta M_{y B}\end{array}$ & $\begin{array}{c}\text { Normalized Blade Root Stress } \\
\Delta \sigma_{y B}\end{array}$ & Load Frequency \\
\hline 1 & 0.05 & 0.04 & $2 \mathrm{~Hz}$ \\
\hline 2 & 0.28 & 0.23 & $2 \mathrm{~Hz}$ \\
\hline 3 & 0.37 & 0.39 & $0.5 \mathrm{~Hz}$ \\
\hline 4 & 0.56 & 0.62 & $0.5 \mathrm{~Hz}$ \\
\hline
\end{tabular}

\section{4. 実験結果および考察}

\section{$4 \cdot 1$ 絽り返し荷重実験結果}

本繰り返し荷重実験での応力振幅の印加状況の一例として, 振幅条件(正規化応力振幅 $\Delta \sigma_{y B}=0.23$ )での時系列デ 一タを図 4 に示す．なお図 4 の緹軸は正規化応力であり，横軸は経過時間である.

また, 各荷重振幅ケースでの, 荷重一応力のヒステリシスループ(20 サイクル分)を図 5 に示す. なお図 5 の縦軸 は正規化曲げモーメントであり，横軸は正規化応力である.

応力振幅の時系列からも，均一な正弦波としての応力振幅が保てていることが分かる．またヒステリシスルー プは, 応力振幅の変化に係わらず,ほぼ線形の変化傾向を保ちヒステリシス自体の非常に小さいことが確認でき, 良好な試験状態であることが確認された。 


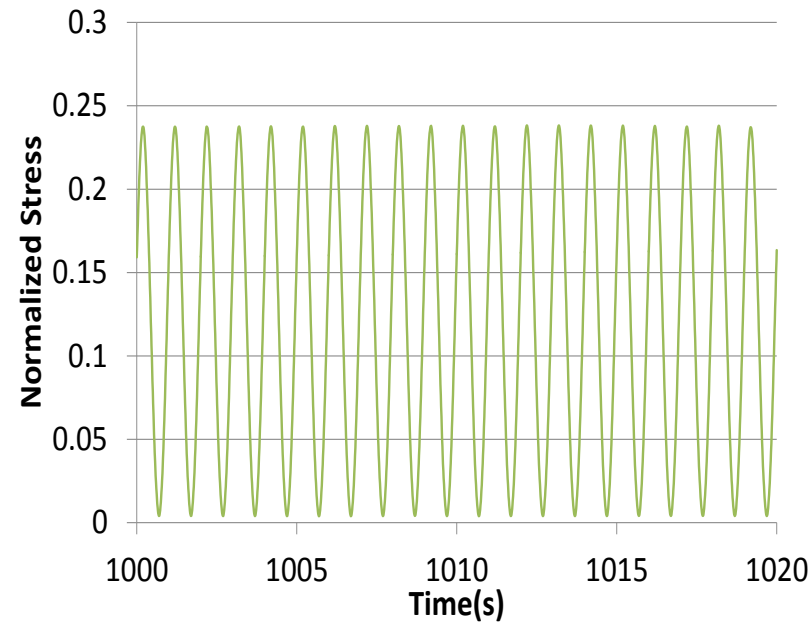

Fig. 4 The time series of stress amplitude. The amplitude condition of this data is $\Delta \sigma_{y B}$ of 0.23 . This data is normalized based on the material tensile strength. In this graph, it is shown that the cyclic loads is maintained the uniform sine wave during the test.

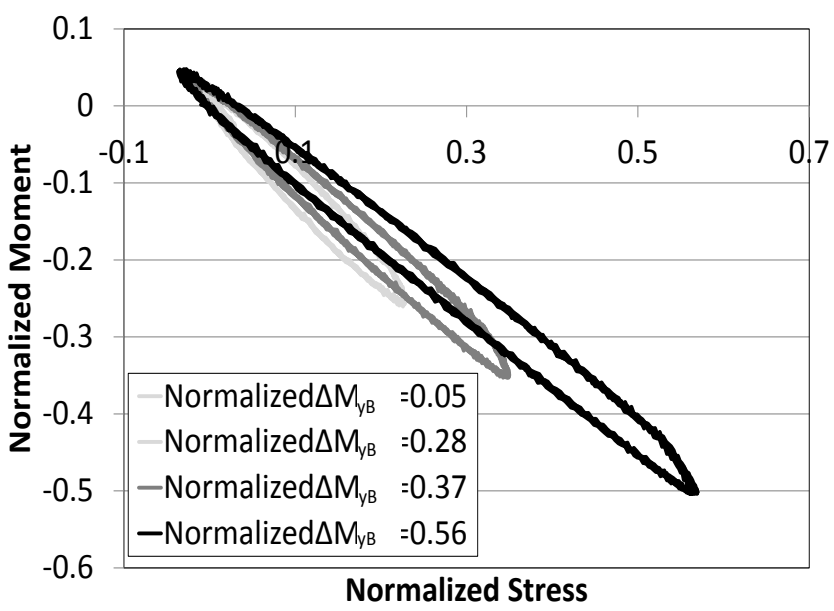

Fig. 5 The hysteresis loop. These hysteresis loops are consisted by the 20 cycle data. In addition, the vertical axis is normalized based on the ultimate bending momentum by the blade static load test. It is confirmed that this experiment is valid because these hysteresis loop are linear tendency.

\section{$4 \cdot 2$ 応力と破断回数の関係}

S-N 線図を図 6 に示寸. 正規化応力振幅 $\left(\Delta \sigma_{y B}\right)$ が，0.04 と 0.23 については本実験の最大繰り返し回数 $10^{6}$ 回に達 しても亀裂など異常が無いことを確認した. 特に 0.23 についは, 繰り返し荷重実験後, 再度静荷重試験を行っ たが, 繰り返し荷重実験前の特性と同一の結果となり, 材料劣化はないと判断できる. $\Delta \sigma_{y B}$ が 0.39 での実験では, 約 80 万回でブレード根元に亀裂が確認され, その亀裂は回数増に従って進展し, 約 98 万回で破断に至った. $\Delta \sigma_{y B}$ 0.62 については約 7000 回で亀裂が発生し，その後わずか 1500 回経過後（8500 回）で破断に至った. なお亀裂の 発生状況を図 7 に示寸．図中の枠で囲った箇所が亀裂発生部である.

図 8 には当該ブレードと同一材料の S-N 線図を示寸. (材料メーカ提供) このデータは ISO3167 の規格に準拠し た試験片による疲労試験結果だが，本研究での実験結果 $\left(\Delta \sigma_{y B} 0.39\right.$ で 80 万回) は, メーカ試験による S-N 線図に 近似していることが確認された，今後統計的考察および検証は必要であるが，単一構成材料では，ブレードの疲 労評価に材料特性值としての S-N 線図データの利用できる可能性を示した.

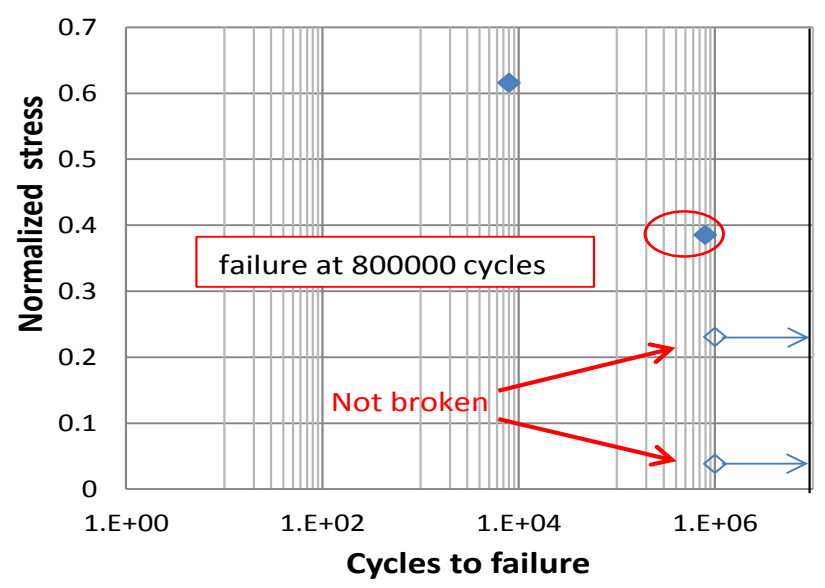

Fig. 6 Fatigue load test result(S-N). In the case of the stress ratio $\left(\Delta \sigma_{y B}\right)$ of 0.04 and 0.23 , it is confirmed that the blade is not broken in spite of the achieving to the cycle number of $10^{6}$.

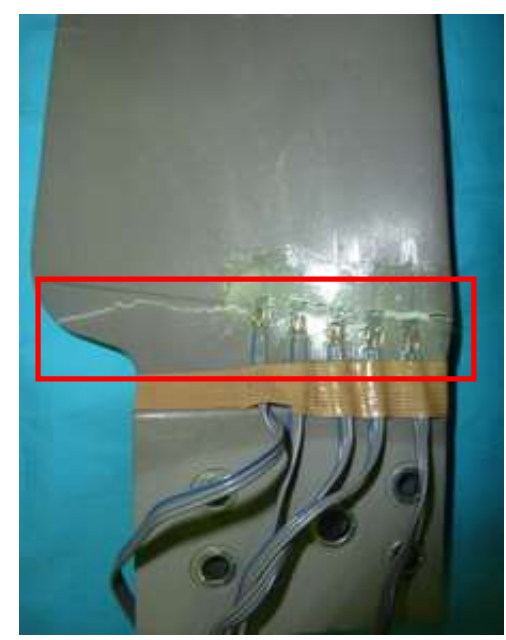

Fig. 7 Brake condition. The arising point of the crack is shown in the red frame. 


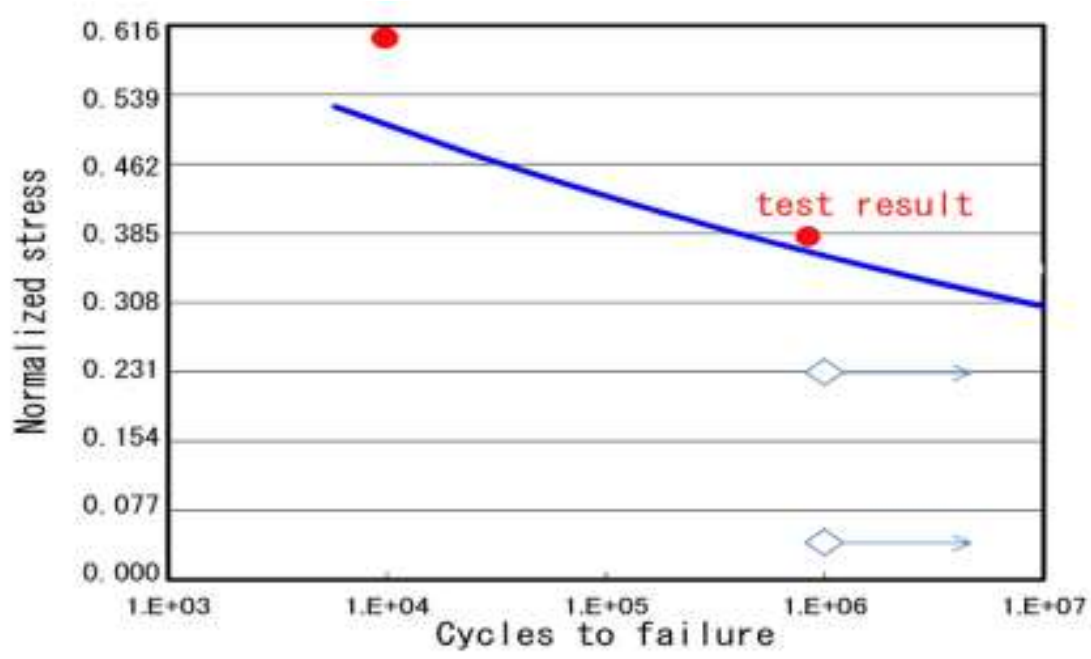

Fig. 8 The comparison between test result and catalogue data. The experiment result shows the red point, and the catalog data shows the blue line. This experimental result that is the breaking in cycle number of 80 million with the stress amplitude $\Delta \sigma_{y B}$ of 0.39 is corresponds to the catalog data (blue line).

\section{$4 \cdot 3$ 等価疲労荷重評価における S-N 線図の想定}

本研究では，空力弾性モデリングで用いられる等価疲労荷重評価を小形風車にも適用することを目的としてい る. 等価疲労荷重 $D E L$ は, 以下の式で示される. 式中の $m$ は想定した材料の S-N 線図の逆数の傾きであり, 材 料の違いによる重みづけを意味する.なお式中の $F_{i}$ は各ビンによる荷重であり, $n_{i}$ は $F_{i}$ に対応する年間発生回数, さらに $N$ はEL に対応する繰り返し荷重回数を示す.

$$
D E L=\sqrt[m]{\frac{\sum_{i} F_{i}^{m} n_{i}}{N}}
$$

\section{等価疲労荷重評価にあたり、 $m$ を推定する必要がある。}

実際の材料疲労設計における $m$ の推定は、特に材料データが無い場合, 同一応力振幅にて複数回実施した材料 の疲労試験データから，破壊における確立論(Probability theory)を導入した P-S-N 線図をもとに，材料のばらつき 特性について統計的に把握したうえ求めることが重要である. 一方, 本研究では各応力振幅に対して単発の繰り 返し疲労実験に留まっているため今後統計的検証も要するが，実験結果が同一材料における材料データと比較的 整合が取れていることを鑑みて，この実験結果を用いて試行的に $m$ の推定を行うこととした.

式(4)および式(5)は材料の S-N 線図のモデル式である(日本鋼構造協会，2012)．なお $\Delta \sigma_{f}$ は S-N 線図上の任意の 応力振幅 $(\mathrm{MPa}), N_{f}$ は $\Delta \sigma_{f}$ に対応寸る破断回数である. これらの式及び実験での破断応力 $0.39,0.62$ の結果から $m$ を得た. $m$ の值を変化させたときの S-N 線図モデルおよび実験值が合致するときの $m$ の関係について示したもの を図 9 に示す.

$$
\begin{aligned}
& C_{O}=\Delta \sigma^{m} \cdot N \\
& C_{O}=\Delta \sigma_{f}{ }^{m} \cdot N_{f}
\end{aligned}
$$

図 9 に示すように $m=10$ のときに実験結果と極めて良好な一致を示すことが確認できた. なお $m=10$ は G-FRP として一般的に適用されている值だが(鈴木他，2011), 当該材料のように熱可塑性のガラス繊維強化材におい ても $m=10$ が適用できることが示された. 


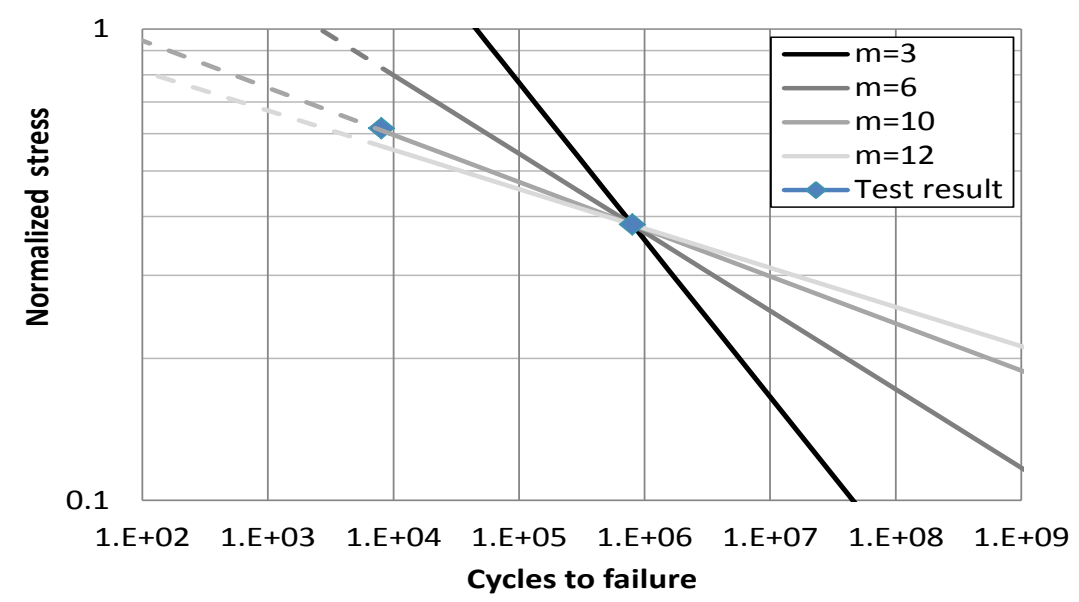

Fig. 9 Estimation of $m$. This graph is shown the value of $m$ when the experimental value corresponds to the S-N diagram model. The value of $m$ of this blade material is estimated 10 by it.

\section{IEC 61400-2 簡易荷重計算モデルにおける等価疲労荷重の提案}

SLM による疲労荷重評価は, 2 章に示したように振幅の代表値を与える. また, この疲労荷重の変動は式(2) で示されているとおり 1 秒間に数回から十数回発生するような短周期成分であるため, SLM にて与えられる振 幅の代表值の定義 $\left(0.5 V_{\text {design }}\right.$ から $1.5 V_{\text {design }}$ の範囲で変動 $)$ が, 年平均風速 $V_{\text {ave }}$ と年間の風速発生頻度との関係を 包含したものでないことが推察される．この考えをもとに，本研究ではSLM で示されたブレードフラップ方 向の疲労荷重振幅 $\Delta M_{y B}$ 自体は風速頻度分布と独立の関係であるものとし，その荷重振幅の代表值を与える風 速 $V_{\text {design }}$ に風速頻度分布の要素を取り入れることで，疲労荷重振幅自体に分布をもたせることを試みた．そし て得られた疲労荷重振幅の分布から，簡便に等価疲労荷重を算出する手法の提案を行った.

\section{$5 \cdot 1$ SLM を用いた等価疲労荷重の算定手法}

本稿では前述した SLM による単一疲労荷重(式(1)) および，その発生回数(式(2))を用い，IEC 61400-2 に示さ れている SWT 風車クラスにて分類された年平均風速の関係から, 風車クラス毎の等価疲労荷重を求める手法を 提案する. その手順について図 10 に示す.

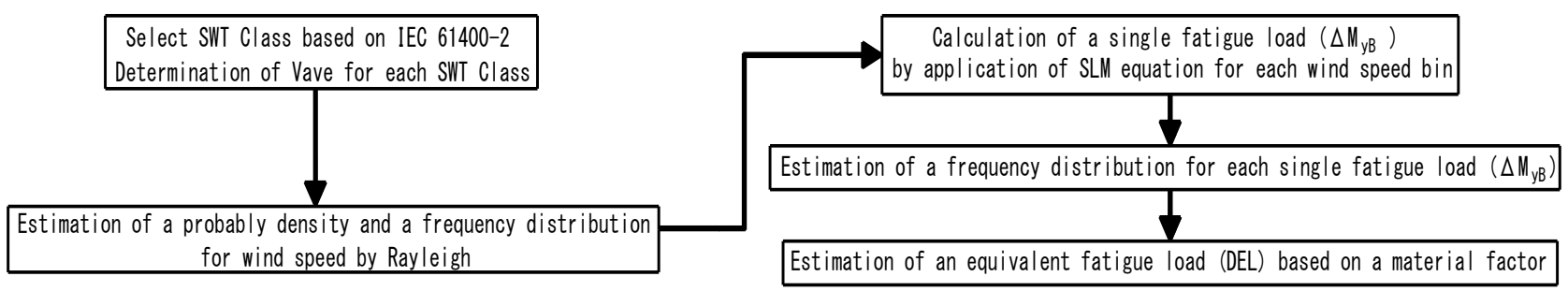

Fig. 10 Calculation procedure of equivalent fatigue load based on SLM

まず IEC 61400-2 に記載の風車クラスを選定する. そのクラスに対応した年平均風速 $V_{\text {ave }}$ (クラス I の場合 $10 \mathrm{~m} / \mathrm{s}$ ) をもとにレイリー分布から風速の確率密度関数を導き， $1 \mathrm{~m} / \mathrm{s}$ バンドによる風速出現率を求める.つぎに式(1)を もとに各風速ビンにおけるフラップ方向の単一疲労荷重 $\Delta M_{y B-i}$ を式(6)のように求め, さらに任意の期間(たとえ ば 1 年間)における各風速ビンの発生累積時間と式(2)の関係から, 各風速ビンに対応する単一疲労荷重の頻度を 式(7)のように展開することで求める. ここで式(6)の $\Delta M_{y B-i}$ は, 各風速ビンに対応する疲労荷重振幅(ブレードフ ラップモーメント振幅 $\mathrm{Nm}$ ) であり， $Q_{i}$ は各風速ビンに対応する風車軸トルク $(\mathrm{Nm})$ である. また式(7)の $N_{i}$ は各 風速ビンにおける疲労荷重振幅の発生回数であり, $f(x)$ はレイリー分布による SWT クラスの年平均風速 $V_{a v e}$ に対 応した風速の確率密度関数, $a_{i}$ と $b_{i}$ は任意の風速ビン区間の範囲 $\left(a_{i}\right.$ は低速側, $b_{i}$ は高速側 $)$ を示し,$n_{i}$ は任意の風 
速ビンにおける風車回転数 (rpm) である. 最後に各風速ビンに対応した疲労荷重の頻度分布から任意の対応年数 (たとえば 20 年)における等価疲労荷重を, 式(3) と本研究にて得られた材料係数 $m=10$ によっ求める.

$$
\begin{aligned}
& \Delta M_{y B-i}=\frac{\lambda_{\text {design }} Q_{i}}{B} \\
& N_{i}=\left\{\int_{a_{i}}^{b_{i}} f(x) d x\right\}\left(\frac{B \cdot n_{i}}{60}\right) T_{d}
\end{aligned}
$$

\section{$5 \cdot 2$ SLM 疲労荷重の頻度分布の算出}

表 3 に IEC 61400-2 記載の風車クラスにおける年平均風速について示寸 (International electrotechnical commission, 2006). この年平均風速に対応するレイリー分布関数から, 風速の確率密度関数を導いたものを図 11 に示す.

Table 3 SWT class

\begin{tabular}{|c|c|c|c|}
\hline \multicolumn{4}{|c|}{ SWT Class $\left(V_{\text {ave }}\right)$} \\
\hline & & & \\
I & II & III & IV \\
$(10 \mathrm{~m} / \mathrm{s})$ & $(8.5 \mathrm{~m} / \mathrm{s})$ & $(7.5 \mathrm{~m} / \mathrm{s})$ & $(6 \mathrm{~m} / \mathrm{s})$ \\
& & & \\
\hline
\end{tabular}

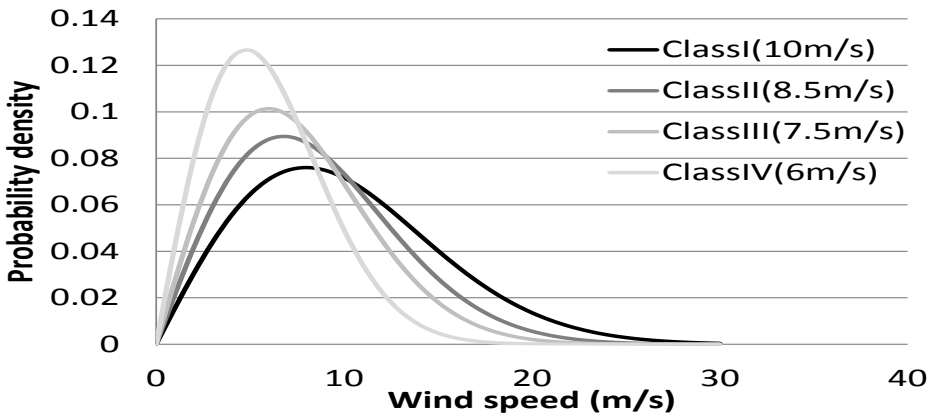

Fig. 11 Probability density function of wind speed. This graph is shown the probability density of wind speed for the annual average wind speed each SWT class that is indicated in IEC 61400-2.

これに式(6) と式(7)を用いて疲労荷重 $\Delta M_{y B-i}$ の頻度分布を求めたものを図 12 に示寸. なお図 12 における頻度 分布は対応年数を 1 年間としたものである. 図の横軸は $\Delta M_{y B-i}$ を, 縦軸は発生頻度を示し, 各系列は風車クラス を示している．当該頻度分布は，風車のカットイン風速，カットアウト風速を運転風速範囲として導いているた め, グラフ横軸の荷重範囲は変わらない。この荷重範囲は, AURA1000のカットイン, カットアウト風速である $2 \mathrm{~m} / \mathrm{s}$ から $16 \mathrm{~m} / \mathrm{s}$ の風速範囲により導かれたものである.

疲労荷重の頻度は, 年平均風速が高い風車クラスになるほど大きい荷重側にシフトし, 本提案にて算出された 疲労荷重頻度分布は風況を反映したものであることがわかる。

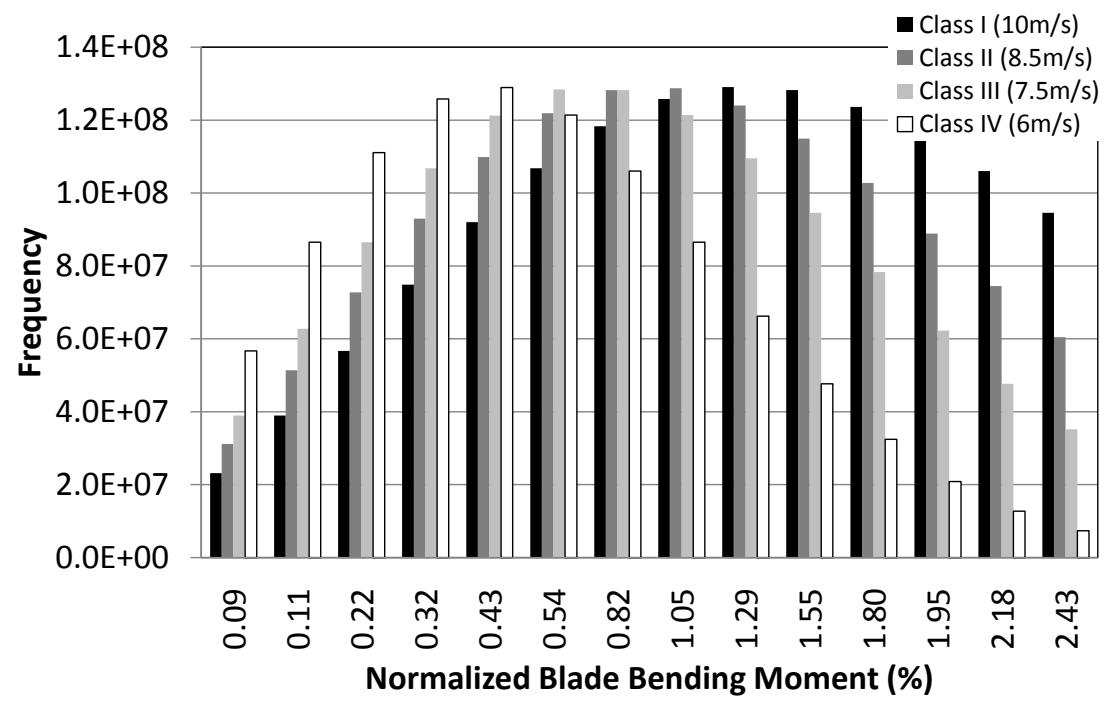

Fig. 12 Annual frequency distribution of fatigue load. This graph is shown the frequency of the fatigue load $\Delta M_{y B-i}$ by calculating with formula (6), (7). In addition, this frequency is composed as the period of durability of 1 year. 


\section{$5 \cdot 3$ 等価疲労荷重の算出}

前節で求めた単一疲労荷重の頻度分布をもとに, 4.3 節で求めた $m=10$ を代入した式(3)により, 20 年間に相当 する等価疲労荷重の算出を試みた。

本研究で提案した手法により算出した等価疲労荷重(以下 $D E L-P$ )について，表 4 に示す.

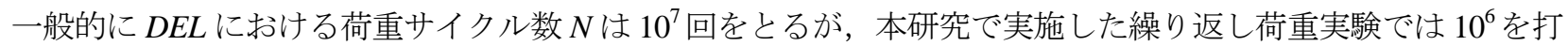
ち切りとして実施した関係から，DEL-P の算出はサイクル数を $10^{6}$ 回でも行った. なお DELの算出結果について も静荷重試験におけるフラップ方向破断モーメントにて正規化している.

Table 4 Estimation of Normalized DEL from Proposed method

\begin{tabular}{|c|c|c|c|c|}
\hline \multirow{2}{*}{$\begin{array}{c}\text { Num. Cycles } \\
\text { for } D E L\end{array}$} & \multicolumn{4}{|c|}{ SWT Class $\left(V_{\text {ave }}\right)$} \\
\cline { 2 - 5 } & $\begin{array}{c}\text { I } \\
(10 \mathrm{~m} / \mathrm{s})\end{array}$ & $\begin{array}{c}\text { II } \\
(8.5 \mathrm{~m} / \mathrm{s})\end{array}$ & $\begin{array}{c}\text { III } \\
(7.5 \mathrm{~m} / \mathrm{s})\end{array}$ & $\begin{array}{c}\text { IV } \\
(6 \mathrm{~m} / \mathrm{s})\end{array}$ \\
\hline $10^{6}$ & 0.05 & 0.05 & 0.05 & 0.04 \\
\hline $10^{7}$ & 0.04 & 0.04 & 0.04 & 0.03 \\
\hline
\end{tabular}

つぎに本研究にて提案した $D E L-P$ と, SLM により求めた $D E L$ (以下, $D E L-S)$ との比較を行った. なお両手法によ るDELの比較評価にあたり, 繰り返し回数をSLM の考えに統一した. SLM の疲労荷重頻度の式(2)に, 耐用年 数 20 年および AURA1000 の設計風速 $V_{\text {design }}$ での回転数, ブレード枚数を入力することで DEL-S としての繰り返 し回数は， $6.3 \times 10^{8}$ と求まる. この回数をもとに, DEL-P と DEL-S との比較を行ったものを図 13 に示す.

図 13 から, DEL-P と DEL-S との差は SWT クラスによって大きく異なることが分かる.クラス IV では 2 倍以上 DEL-P の方が高い值を示すが，その差は SWT クラスが高くなるにつれて縮まり，クラス I なると約 $5 \%$ クはあ るが DEL-S の方が高い值を示す.

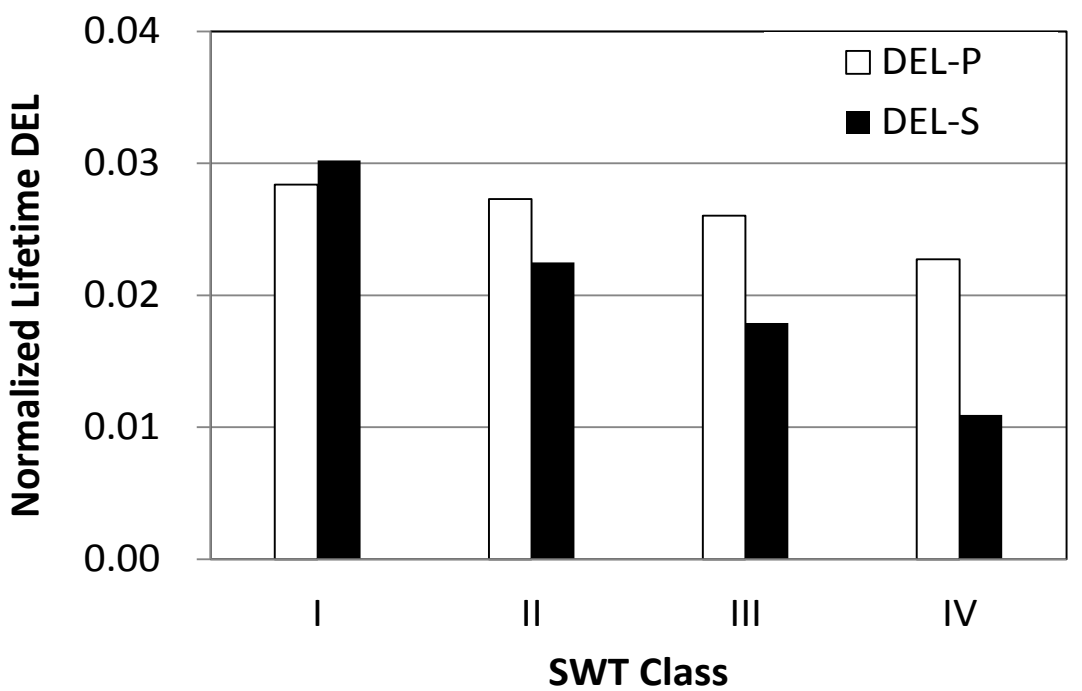

Fig. 13 Comparison of DEL between Proposed method and SLM. These DEL values are calculated based on the number of cycle of $6.3 \times 10^{8}$ each SWT-class. The value of $D E L-P$ is 2 times larger than $D E L-S$ in SWT-class IV. Then the differential between $D E L-P$ and DEL-S is decreased according to rise the SWT-class, and the value of $D E L-S$ is $5 \%$ larger than $D E L-P$ in SWT-class I.

本研究で提案した手法による DEL-P は, 各 SWT クラスに対応する疲労荷重振幅の頻度分布をもとに算出され る.またこの頻度分布は，5.2 節で述べたとおり風速頻度だけでなく，風車のカットイン，カットアウト風速にも 影響される。

一方 DEL-S は, $V_{\text {design }}=1.4 V_{\text {ave }}$ によって特定される風速に対応する荷重振幅を常に経験する想定のもと求められ ている.（ $V_{\text {design: }}$ Class I=14 m/s，Class II $=11.9 \mathrm{~m} / \mathrm{s} ，$ Class III $=10.5 \mathrm{~m} / \mathrm{s} ，$ Class IV=8.4 m/s）

従って，SLM で特定される風速と供試風車のカットアウト (AURA1000 の場合 $16 \mathrm{~m} / \mathrm{s})$ が近づくにつれて，互い のDELの差は縮まることとなる. 
Tokuyama, Takahashi, Iino and Iida, Transactions of the JSME (in Japanese), Vol.80, No.816 (2014)

風速頻度分布の要素を含めた $D E L-P$ に対して, $D E L-S$ は, SWT クラスの違いによる変化が大きく, クラスが低 くなるにつれて過小評価となっていることが懸念される.

一方 DEL-P は, クラス I では DEL-S に比べて若干の過小評価となるものの，全体的に疲労設計として安全側の 結果となり，またこの算出值は SWT クラスだけでなく，対象風車のカットイン，カットアウト風速も算出因子 となることから，風車の設計要件も反映された，より現実的な方法であるものと考える.

今後, 本手法については, 空力弾性モデルとの比較検証を行い, その妥当性について評価する. また本研究成 果をもとに，小形風車ブレードの疲労設計における材料安全率の適用についても検討寸る予定である.

\section{6. 結 言}

本論文では，小形風車ブレードとして一般的な単一構成材料による実機での繰り返し荷重実験を実施し，小形 風車ブレードの疲労設計さらには等価疲労荷重評価についての一提案として検討を行った.

繰り返し荷重実験から,ブレード実機での実験結果とメーカ提示の試験片によるデータとは比較的整合がとれ, 疲労荷重評価を行う上でメーカ提示の S-N 線図を利用できる可能性を示すことができた. さらに簡易荷重計算モ デル(SLM)をもとに疲労荷重の頻度分布を推定することで, 等価疲労荷重評価を簡便かつ, 従来の SLM に基づく 評価方法に比べてより現実的なものとして行える手法を提案した.

\section{謝 辞}

本研究の一部は NEDO 事業「次世代風力発電技術研究開発（基礎・応用技術研究開発）」による協力を受ける ことで行いました，本事業にご協力頂きました関係各位に感謝申し上げます.

\section{文献}

赤星貞夫, 小形風力発電, 設備認証機関としての役割, 風力エネルギー, Vol.36,No.3(2012),pp.368-372.

International electrotechnical commission, Wind turbines. Part 2: Design requirements for small wind turbines (2006).

日本小形風力発電協会, 小形風車の性能及び安全性に関寸る規格 (2011).

日本鋼構造協会，鋼構造物の疲労設計指針・同解説(2012), pp.27-30.

鈴木潤, 武藤 厚俊, 久保典夫, JSW J82-2.0 における等価疲労荷重評価, 第 33 回風力エネルギー利用シンポジウ 么(2011),pp.237-239.

\section{References}

Akahoshi, S., Small wind turbine, a role of the certification body, Wind Energy, Vol.36, No.3(2012), pp. 368-372 (in Japanese).

International electrotechnical commission, Wind turbines. Part 2: Design requirements for small wind turbines (2006). Japan small wind turbine association, Small wind turbine performance and safety standard (2011) (in Japanese). Japanese Society of Steel Construction, Fatigue design recommendations for steel structures (2012), pp. 27-30(in Japanese). Suzuki, J., Muto, A. and Kubo, N., Damaged equivalent load assessment for JSW J82-2.0, Proceedings of Japan Wind Energy Symposium, The 33rd (2011), pp. 237-239 (in Japanese). 